Estudios Constitucionales, Año 12, No 2, 2014, pp. 275-300.

ISSN 07180195

Centro de Estudios Constitucionales de Chile Universidad de Talca

"O princípio do nível de proteção mais elevado: análise do artigo 53 da Carta dos

Direitos Fundamentais da União Europeia à luz do Acórdão Melloni”

Pedro Miguel Alves Ribeiro Correia e Inês Oliveira Andrade de Jesus

\title{
O PRINCÍPIO DO NÍVEL DE PROTEÇÃO \\ MAIS ELEVADO: ANÁLISE DO ARTIGO 53 \\ DA CARTA DOS DIREITOS FUNDAMENTAIS DA \\ UNIÃO EUROPEIA À LUZ DO ACÓRDÃO MELLONI*
}

EL PRINCIPIO DEL MÁXIMO NIVEL DE PROTECCIÓN: ANÁLISIS DEL artículo 53 de la Carta de los Derechos Fundamentales de

la Unión Europea a la luZ de la sentencia Melloni

THE PRINCIPLE OF THE HIGHEST LEVEL OF PROTECTION: ANALYSIS

of ARTICle 53 ot the Charter of Fundamental Rights of the

European Union in the Light of The Melloni Judgment

Pedro Miguel Alves Ribeiro Correia ${ }^{* *}$

Professor da Universidade de Lisboa, Portugal

Inês Oliveira Andrade De Jesus***

Doutoranda da Universidade Nova de Lisboa, Portugal

RESUMO: Neste artigo é apresentada uma análise do artigo 53 da Carta dos Direitos Fundamentais da União Europeia e das principais questōes jurídicas que lhe são confluentes. São abordados temas como a União (Constitucional) Europeia, os trabalhos preparatórios que precederam a redação do artigo 53 da Carta dos Direitos Fundamentais da Uniāo Europeia, a análise e enquadramento sistemático desta norma e a análise do acórdão Melloni. Por fim, é feita uma apreciação crítica do artigo 53.

PalaVRAS-CHAVE: Princípio do nivvel de proteção mais elevado, União Europeia, Carta dos Direitos Fundamentais, acórdão Melloni, artigo 53.

* Trabajo recibido el 2 de octubre de 2013 y aceptado el 26 de noviembre de 2013.

** Doutorado em Ciências Sociais na Especialidade de Administração Pública pela Universidade Técnica de Lisboa (UTL); Licenciado em Estatística e Gestão de Informação pela Universidade Nova de Lisboa (NOVA); Professor do Master in Public Administration - Administração da Justiça, do Instituto Superior de Ciências Sociais e Políticas (ISCSP) da Universidade de Lisboa (ULisboa); Investigador integrado no Centro de Administração e Políticas Públicas (CAPP), ISCSP-ULisboa; Consultor da Direção-Geral da Política de Justiça (DGPJ) do Ministério da Justiça de Portugal. pcorreia@iscsp. ulisboa.pt

${ }^{* * *}$ Doutoranda em Direito na Universidade Nova de Lisboa (NOVA); Mestre em Direito pela Universidade Nova de Lisboa (NOVA); Licenciada em Direito pela Universidade Nova de Lisboa (NOVA); Consultora da Direção-Geral da Política de Justiça (DGPJ) do Ministério da Justiça de Portugal.000943@fd.unl.pt 
RESUMEN: Este artículo presenta un análisis del artículo 53 de la Carta de los Derechos Fundamentales de la Unión Europea y los principales aspectos legales que son confluentes con esta norma. Son abordados temas como la Unión (Constitucional) Europea, los trabajos preparatorios que precedieron a la redacción del artículo 53, la Carta de los Derechos Fundamentales de la Unión Europea, el análisis y la estructura sistemática de esta norma y el análisis de la sentencia Melloni. Por último, se hace una evaluación crítica del artículo 53.

PalabRAS-CLAVE: Principio del máximo nivel de protección, Unión Europea, Carta de los Derechos Fundamentales, sentencia Melloni, artículo 53.

ABSTRACT: This paper presents an analysis of article 53 of the Charter of Fundamental Rights of the European Union and of its' major confluent legal issues. Topics such as the European (Constitutional) Union, the preparatory work that preceded the drafting of article 53 of the Charter of Fundamental Rights of the European Union, the analysis and systematic framework of this norm and the analysis of the Melloni judgment, are addressed. Finally, a critical assessment is made on article 53.

KEYWORDS: Principle of the highest level of protection, European Union, Charter of Fundamental Rights, Melloni judgment, article 53.

\section{INTRODUÇÃO}

O apelidado projeto europeu há muito que declinou essa qualificação. Hoje, a União Europeia é um dado da realidade, que, não obstante todas as dificuldades, espelha um processo de integração coeso.

$\mathrm{Na}$ verdade, apesar do fracasso do projeto de Tratado que estabelecia uma Constituição para a Europa, arrasado nas urnas francesas e holandesas nos referendos de 29 de maio e 1 de junho de 2005, respetivamente, e que se traduziu num freio à construção europeia, o novo projeto de Tratado, arquitetado no Conselho Europeu de 23 de junho de 2007 e assinado em Lisboa a 13 de dezembro do mesmo ano, contribuiu para dar um novo fôlego no sentido da inclusão europeia.

O Tratado de Lisboa, que entrou em vigor em 1 de dezembro de 2009, aprovou o Tratado da União Europeia (TUE), o Tratado sobre o Funcionamento da União Europeia (TFUE) e a Carta dos Direitos Fundamentais da União Europeia (Carta), os quais completam o acervo jurídico primário da União.

Pela primeira vez na história da União Europeia, o TUE reconheceu expressamente os valores fundamentais da União. Na verdade, o artigo $2^{\circ}$ consagra os princípios da dignidade humana, da liberdade, da democracia, da igualdade, do Estado de Direito e do respeito dos direitos humanos.

Os avanços e recuos da construção europeia foram sempre acompanhados pelo alegado problema do reduzido nível de participação dos cidadãos da União, que, para muitos, se reflete no défice democrático e na inexistência de órgáos verdadeiramente representativos. $\mathrm{Na}$ realidade, o facto de o constitucionalismo europeu aparecer como uma simples decorrência do processo de integração do 
mercado económico é apontado como a razão do enfraquecimento da legitimidade do processo constitucional europeu, a que acresce a suposta inexistência de uma comunidade política à escala europeia e de um acordo sobre quem detém a competência das competências.

No entanto, o valor da democracia há muito que foi afirmado na Comunidade, muito antes de constar explicitamente no articulado do TUE. Já em 1973, o documento sobre a identidade europeia adotado em Copenhaga sublinhava a vontade de salvaguardar o princípio da democracia representativa. Mais tarde, o Ato Único Europeu acolheu, no preâmbulo, o princípio democrático, princípio este que foi afirmado várias vezes pelo Tribunal de Justiça (TJ).

Ora, o valor da democracia postula, como sabemos, que o poder provém do povo, é exercido pelo povo e para o povo. Os cidadãos devem, assim, eleger os órgãos políticos, devem poder participar na adoção das decisões políticas e devem dispor do poder de controlar os governantes.

Pois bem, é este princípio democrático que explica algumas das reformas operadas pelo Tratado de Lisboa. Vejamos. Foram consagrados, pela primeira vez, nos artigos $9^{\circ}$ a 12 do TUE, decorrências do princípio democrático, tal como foi levada a cabo uma reforma institucional com vista a democratização da União. E, sublinhe-se, os desvios ao princípio democrático no âmbito da Política Externa e de Segurança Comum e do Espaço de Liberdade, Segurança e Justiça não implicam, necessariamente, a negação da democracia europeia e do constitucionalismo europeu.

Aliás, Miguel Poiares Maduro defende que a União Europeia se traduz numa "mais-valia constitucional e democrática face ao constitucionalismo nacional", revelando, pois, um "superavit democrático" ou um "valor democrático acrescentado"1. A União Europeia, enquanto ente constitucional, não pode prescindir, pois, dos princípios democráticos, visto ser a democracia um pressuposto primário dos atuais quadros constitucionais, nos quais se inclui a União. Além disso, é uma União de direitos, que reconhece e protege os direitos fundamentais, robustecida pela já referida Carta dos Direitos Fundamentais da União Europeia, à qual o TUE atribuiu o mesmo valor jurídico dos Tratados. A consagração do carácter vinculativo deste catálogo de direitos fundamentais traduziu-se, pois, num passo ímpar da construção europeia, passo este que foi acompanhado pelo acentuar da querela em torno dos conflitos jurídico-constitucionais decorrentes da colisão entre os direitos nacionais e o ordenamento jurídico europeu.

1 Maduro, 2001, pp. 120 e 121. 
Neste contexto, o recente Acórdão Melloni deu o mote para o presente trabalho. Com efeito, a discussão em torno do artigo 53 da Carta, em especial, sobre a eventual consagração do princípio do nível de proteção mais elevado, há muito que estava presente nas resenhas doutrinárias sobre o tema. OTJ, apesar de nunca se ter pronunciado especificamente sobre a matéria, parecia não abandonar a linha jurisprudencial do princípio do primado do direito da União.

\section{A União (Europeia) Constitucional}

O termo "Constituição", tradicionalmente associado aos Estados-nação, sempre expressou, acolhendo, o elenco de direitos e deveres fundamentais das pessoas, as normas relativas à organização do poder político, o sistema das fontes de direito infraconstitucional, o estabelecimento do processo específico da sua revisão e a consagração de valores e princípios basilares. Na verdade, desde sempre, a Constituição é vista como um instrumento jurídico de garantia da liberdade individual e de limitação e legitimação do poder político. Por essa razão, Poiares Maduro sublinha "a verdadeira natureza do constitucionalismo: a de harmonizar e mediar interesses diferentes e frequentemente conflituantes"2.

Atualmente, os ordenamentos jurídico-constitucionais mostram-se altamente complexos, dada a pluralidade de fontes, de intérpretes e de interesses e valores consagrados. Ora, a União Europeia não é exceção, apesar de o constitucionalismo europeu estar repleto de especificidades, formando uma ordem jurídica singular.

$\mathrm{Na}$ verdade, no direito constitucional europeu, as tradiçôes constitucionais nacionais desempenham um papel ativo e de grande relevo, nunca contado pela história, no qual as diferentes ordens jurídicas nacionais, marcadas, sobretudo, pelos contextos sociopolíticos particulares, dialogam de forma concertada.

No entanto, como bem afirma Nuno Piçarra, "o reconhecimento de que a UE se rege por uma constituição não significa de modo nenhum reduzir as constituições dos Estados-Membros "a uma dimensão intermédia de legitimação do fenómeno político na União Europeia", dado que "tais constituições têm-se revelado activamente estruturantes da própria constituição da UE”3.

Assistimos, pois, tal como o adjetiva Ingolf Pernice, a um constitucionalismo a vários níveis, também denominado de pluralismo constitucional ou de interconstitucionalidade.

2 Maduro, 2001, p. 120.

3 PIÇARRA, 2011, p. 12. 
Como já salientamos, o constitucionalismo é a forma primeira de limitação do exercício do poder político, assegurando a autonomia e a liberdade individuais, o que se torna especialmente importante nesta União em permanente construção.

No entanto, na União Europeia, o conceito de constitucionalismo alcançou novos contornos e adquiriu um significado renovado. O projeto europeu, hoje uma realidade firmada, é uma entidade constitucional pós-nacional ou supranacional, caracterizada por uma natureza sui generis.

O constitucionalismo assim arquitetado, visto, sobretudo, como o quadro de princípios e valores fundamentais comuns e de organização e limitação do poder político no âmbito europeu, tem sido alvo de fortes críticas.

$\mathrm{Na}$ verdade, alguns autores, negando a natureza constitucional da União, defendem que a atribuição desta está dependente da existência de um Estadonação. Por outro lado, para outros autores, afirmar a existência de uma tradição constitucional comum aos Estados-Membros é erróneo, dados os diversos contextos sociopolíticos. Outros pensadores sublinham, ainda, a desconsideração de outros mecanismos, o que leva a um fetichismo constitucional, tal como a autoridade simbólica do termo e a indeterminação conceptual do mesmo.

Entendemos, no entanto, que a União Europeia é, verdadeiramente, uma entidade constitucional, cuja constituição agrega as Constituições dos EstadosMembros, traduzidas pelo acervo constitucional comum acolhido nos Tratados.

Na senda de Nuno Piçarra, "o facto de os três instrumentos jurídicos por que se dispersa o estatuto jurídico-político fundamental da UE (TUE, TFUE e CDFUE) também regularem as mesmas questôes que qualquer constituição estadual regula, longe de induzirem a sua natureza constitucional, reflectem-na" ${ }^{4}$. E, sublinhe-se, "o constitucionalismo nacional não beneficia a priori de uma legitimidade superior à do constitucionalismo europeu" 5 .

Esta entidade constitucional é recorrentemente caracterizada de sui generis, na medida em que concretiza um conceito de constituição pós-nacional. $\mathrm{Na}$ verdade, deparamo-nos, no processo de integração, com o reconhecimento de múltiplas identidades políticas, que se traduzem nas estreitas relações entre as Constituições dos Estados-Membros e a constituição europeia, espelhada pelo direito primário da União.

O Tratado de Lisboa é, pois, um tratado materialmente constitucional, pelo que a ausência do termo constituição e da terminologia constitucional não é

4 PiÇARRA, 2011, p. 11.

5 Maduro, 2001, p. 122. 
decisiva. Com a sua assinatura, tornou-se premente a adoção de uma conceção diferente do constitucionalismo, no qual a reforma dos processos políticos e o desenvolvimento de novos direitos de representação e participação se tornam cruciais para o reforço da dimensão cidadã da União.

Este constitucionalismo multinível a que assistimos, decorrente da pluralidade de comunidades políticas nacionais, apela ao diálogo entre os constitucionalismos nacionais e europeu.

Por outro lado, acentua-se a transferência de soberania e de competências dos Estados-Membros para a União Europeia, que se repercute na crescente interdependência dos ordenamentos jurídicos nacionais e europeu e na aplicação concorrente de disposiçôes normativas. Este contexto mostra-se, pois, favorável, ao aparecimento de conflitos normativos. As incompatibilidades tendem a ser cada vez mais e mais complexas, dado o referido número crescente de competências partilhadas, a que acrescem os diferentes standards de proteção nacionais e europeu.

Tendo em conta este aumento de conflitos, o diálogo jurisprudencial entre o TJ e os tribunais nacionais será fulcral, desempenhando a instância europeia o papel principal.

Aliás, recorde-se que foi o próprio TJ que, desde a década de 60 do século passado, começou a trilhar o difícil processo de constitucionalização da atual União Europeia.

Evoque-se o Acórdão Van Gend en Loos, de 5 de fevereiro de 1963, no qual encontramos o primeiro afloramento à aplicabilidade direta das disposiçóes do então denominado direito comunitário, não só às instituições europeias e aos Estados-Membros, mas também aos próprios cidadãos.

Por outro lado, e de inegável importância, o Acórdão Costa Enel, de 15 de julho de 1964, proclamou, pela primeira vez, a existência do princípio do primado do direito comunitário sobre o direito interno dos Estados-Membros, mesmo se se tratasse de normas vertidas nas constituições nacionais. Com este aresto precursor, afirmou-se, assim, o princípio da aplicação uniforme e da eficácia do direito europeu.

O TJ também teve um papel crucial no que concerne especificamente à tutela dos direitos fundamentais. Vejam-se os Acórdãos Stauder, de 12 de novembro de 1969, Internationale Handelsgesellschaft, de 17 de dezembro de 1970, e Nold, de 14 de maio de 1974, nos quais se reconheceu a tutela dos direitos fundamentais, tal como consagrados nas constituições nacionais, como parte integrante dos princípios gerais de direito comunitário. Note-se, aliás, que o TJ adotou a retórica dos direitos fundamentais com o propósito de assegurar o respeito pelo princípio do primado já propugnado. 
É de destacar, nesta linha, o Acórdão Rutili, de 28 de outubro de 1975, o qual, pela primeira vez, mencionou expressamente a Convenção Europeia dos Direitos do Homem $(\mathrm{CEDH})$ como o standard de tutela dos direitos fundamentais a ter em conta pelo TJ.

Nos trilhos percorridos até aos dias de hoje, o TJ sempre assumiu as suas limitações relativamente à apreciação de normas nacionais e à sua compatibilidade com os direitos fundamentais.

Veja-se, no entanto, o Acórdão Zambrano, de 8 de março de 2011, o qual, continuando a delimitar a competência do direito da União tendo por bitola as situações puramente internas, afirma que o TFUE obsta a medidas nacionais que tenham o efeito de privar os cidadãos do gozo efetivo do essencial dos direitos conferidos pelo estatuto de cidadão da União, dando assim um passo importante na proteção dos direitos fundamentais.

Por outro lado, o TJ, incomodado com certos casos difíceis de direito constitucional, tem evitado, astutamente, a problemática ponderação de direitos. Veja-se o Acórdão Grogan, de 4 de Outubro de 1991.

Esta pequena resenha jurisprudencial evidencia a importância do TJ na constitucionalização da União. Na verdade, a União Europeia é hoje um ente indiscutivelmente constitucional, que acolhe e postula os princípios e os direitos fundamentais.

\section{A Carta dos Direitos Fundamentais da União Europeia}

Nesta União (Europeia) Constitucional, a Carta torna-se fulcral, estando a sua origem bem distante do acolhimento pelo Tratado de Lisboa. De facto, a génese da Carta dos Direitos Fundamentais da União Europeia remonta ao Conselho Europeu de Colónia de 3 e 4 de junho de 1999, o qual conferiu mandado a uma Convenção para a sua redação.

A referida Convenção foi constituída em dezembro desse mesmo ano de 1999 e era composta por quinze representantes dos Chefes de Estado e de Governo dos Estados-Membros, trinta representantes dos Parlamentos Nacionais, dezasseis representantes do Parlamento Europeu e um representante da Comissão Europeia, sendo presidida por Roman Herzog, o antigo Presidente do Tribunal Constitucional Federal Alemão.

Inserido na Convenção, foi criado um Comité de redação, formado pelo Presidente da Convenção, por um representante de cada uma das instituições da União Europeia e por um representante do país que assumia então a Presidência da União.

Tendo como objetivos principais o reforço da proteção dos direitos fundamentais na União e o aumento da sua visibilidade e compreensão, o Comité elaborou 
uma primeira versão da Carta, que foi objeto de análise e discussão por parte da Convenção. Considerando esta análise e esta discussão, o Comité estava encarregue de proceder às alteraçôes tidas por pertinentes. Posteriormente, deveriam ser realizadas audiçôes às várias organizações interessadas e aos países candidatos à adesão na União. O texto final seria aprovado pela Convenção, em reunião plenária.

Ora, a Convenção aprovou o projeto final em outubro de 2000 no Conselho Europeu de Biarritz, projeto este que mereceu, igualmente, a aprovação prévia do Parlamento Europeu e da Comissão Europeia.

No dia 7 de dezembro de 2000, a Carta foi então assinada e proclamada em Nice pelos representantes do Conselho, do Parlamento e da Comissão Europeia.

Com o Tratado de Lisboa, a Carta tornou-se juridicamente vinculativa, apesar de não ter sido incorporada nos Tratados. Nos termos do artigo $6^{\circ}$ do TUE, a União reconhece os direitos, as liberdades e os princípios enunciados na Carta, que tem o mesmo valor jurídico que os Tratados, apesar de o disposto na Carta não poder, de forma alguma, alargar as competências da União, tal como definidas nos Tratados. Importa notar que, ao abrigo do mesmo artigo, os direitos, as liberdades e os princípios consagrados na Carta devem ser interpretados de acordo com as disposições gerais constantes do Título VII da Carta que regem a sua interpretação e aplicação e tendo na devida conta as anotações a que a Carta faz referência, que indicam as fontes dessas disposições.

Ora, o citado artigo $6^{\circ}$ do TUE, nos $\mathrm{No}^{\text {s }} 2$ e 3, contém normas que alguma doutrina adjetiva de estranhas, podendo, aparentemente, ser explicadas pelo denominado fantasma da declaração de direitos aditada à Constituição federal norte-americana em 1791, que constituiu um dos mais importantes elementos de controlo e reforço da Federação sobre os Estados. Todavia, no que concerne especialmente à União Europeia, a proteção dos direitos fundamentais tem operado de baixo para cima, ou seja, dos Estados-Membros para a União, pelo que a Carta não conseguirá inverter esta situação, na qual as tradições constitucionais comuns continuam a desempenhar um papel preponderante.

A Carta é, pois, um texto proclamatório que não esgota a função garantidora do Tratado de Lisboa, dadas as normas plasmadas no TUE e no TFUE que também consagram direitos e liberdades, e quem, além disso, leva em elevada conta as tradições constitucionais comuns dos Estados-Membros.

A esta declaração de direitos de vocação geral são apontadas várias vantagens, como, por exemplo, a visibilidade e a certeza jurídica, o reconhecimento do estatuto de cidadania da União e a autonomização dos direitos em relação ao vínculo económico, além da coerência sistemática e axiomática que proporcionou no ordenamento jurídico europeu. 
Para finalizar, refira-se o Protocolo relativo à aplicação da Carta ao Reino Unido e à Polónia, que é extensivo à República Checa, o qual consagra um optout destes países relativamente à Carta.

\section{AnÁlise do ARTigo 53 da CARTA}

\subsection{Os trabalhos preparatórios}

Para uma análise profícua do artigo 53 da Carta, objeto do presente trabalho, mostra-se importante examinar os trabalhos preparatórios que conduziram à redação da norma que versa sobre o nível de proteção dos direitos fundamentais.

Ora, em primeiro lugar, recorde-se que o objetivo originário da norma era aclarar as relações entre as disposiçôes da Carta e da CEDH. Por isso mesmo, a primeira redação proposta postulava que nenhuma disposição podia ser interpretada como restringindo a proteção garantida, em conformidade com o disposto no artigo $6^{\circ}$ do Tratado da União Europeia, pela Convenção Europeia dos Direitos do Homem.

Nesta primeira versão, era bem patente a preocupação de assegurar que o nível de proteção dos direitos fundamentais na União não fosse inferior ao estabelecido pela CEDH. A Convenção era, pois, o standard mínimo de proteção dos direitos fundamentais no espaço europeu.

A segunda redação proposta suprimiu a referência ao artigo $6^{\circ}$ do TUE, mantendo-se, no remanescente, igual. Continuava-se, assim, a garantir a proteção mínima da CEDH.

Por sua vez, a terceira redação rezava o seguinte: Nenhuma disposição da presente Carta pode ser interpretada como restringindo o alcance dos direitos garantidos pelo direito da União, pelo direito dos Estados-Membros, pelo direito internacional e pelas convençôes internacionais ratificadas pelos Estados-Membros, nomeadamente a Convenção Europeia dos Direitos do Homem tal como a interpreta a jurisprudência do Tribunal Europeu dos Direitos do Homem (TEDH).

Com efeito, assistiu-se, com a terceira redação, à ampliação do patamar de proteção dos direitos fundamentais, o que despoletou fortes críticas.

Face ao novo texto da norma, a proteção conferida aos direitos fundamentais implicava o respeito do direito da União e dos Estados-Membros, tal como do direito internacional e das convençóes ratificadas, com especial destaque para a $\mathrm{CEDH}$ tal como interpretada pelo TEDH.

Ora, tendo em conta esta nova redação, que foi alvo de variadas críticas, como já foi referido, foram equacionadas as reais implicações da referência ao direito dos Estados-Membros, tendo em conta os princípios do primado e da uniformidade da aplicação do direito comunitário, tal como da referência à jurisprudência do 
TEDH e da desprestigiante omissão ao TJ. Além disso, trouxe-se à colação a eventual confusão entre o poder legislativo e o judicial.

Depois desta controversa redação, o Comité alterou a norma, subtraindo a referência à jurisprudência do TEDH e substituindo a menção ao direito dos Estados-Membros pela mais restritiva referência às constituições nacionais.

Pois bem, a quarta redação foi a seguinte: Nenhuma disposição da presente Carta será interpretada como restringindo ou lesando os Direitos do Homem e as liberdades fundamentais reconhecidos, nos respetivos âmbitos de aplicação, pelas Constituiçóes dos Estados-Membros, pelo direito internacional e pelas convenções internacionais, nomeadamente a Convenção para a Proteção dos Direitos do Homem e das Liberdades Fundamentais.

Ora, além das modificações já elencadas, o Comité introduziu uma menção que limita a norma aos respetivos âmbitos de aplicação. Reforça-se, assim, o princípio do primado, visto que, para alguns autores, as constituiçôes nacionais só poderão prevalecer em matérias de exclusiva competência dos Estados-Membros.

A quarta redação, elaborada pelo Comité, foi apresentada à Convenção para apreciação, esta que, formulando uma panóplia de críticas, propôs alterações de índole muito diversa. Vejamos.

Alguns representantes, mais radicais, propuseram a supressão da norma, enquanto outros pediram a introdução da referência às tradições constitucionalmente comuns em substituição das constituições nacionais. Outros sugeriram a introdução da referência às legislações dos Estados-Membros, às convenções da Organização das Nações Unidas (ONU) e da Organização Internacional do Trabalho (OIT) e à Carta Social Europeia, tal como uma menção expressa à jurisprudência do TEDH, do TJ e dos tribunais nacionais. Outros, ainda, alvitraram a introdução de uma autorização expressa para o estabelecimento de proteção reforçada a nível nacional e de uma norma especial no que toca à interpretação dos direitos económicos, sociais e culturais.

Apesar de todas estas alterações alvitradas, o Comité entendeu, apenas, deslocar para o final da norma a referência às constituiçôes dos Estados-Membros.

Assim, a quinta redação estabelecia que nenhuma disposição devia ser interpretada no sentido de restringir ou lesar os Direitos do Homem e as liberdades fundamentais reconhecidos, nos respetivos âmbitos de aplicação, pelo direito internacional e pelas Convenções internacionais em que são Partes a União, a Comunidade ou os Estados-Membros, nomeadamente, a Convenção Europeia de Proteção dos Direitos do Homem e das Liberdades Fundamentais, bem como pelas Constituiçõos dos Estados-Membros. 
Anexa a esta disposição, a explicação da mesma apontava como objetivo a preservação do nível de proteção proporcionado pelo direito da União, pelo direito dos Estados-Membros e pelo direito internacional. Não obstante, a CEDH seria, em todos os casos, o padrão mínimo a respeitar.

Ora, após uma longuíssima discussão e de inúmeras alterações propostas, foi, então, aprovada a sexta e última redação, que postulava o seguinte: Nenhuma disposição da presente Carta deve ser interpretada no sentido de restringir ou lesar os direitos do Homem e as liberdades fundamentais reconhecidos, nos respetivos âmbitos de aplicação, pelo direito da União, o direito internacional e as Convenções internacionais em que são Partes a União, a Comunidade ou todos os EstadosMembros, nomeadamente, a Convenção Europeia para a Proteção dos Direitos do Homem e das Liberdades Fundamentais, bem como pelas Constituiçóes dos Estados-Membros. Eis, pois, a redação atualmente em vigor.

\subsection{Enquadramento sistemático}

Tendo em conta o objetivo deste trabalho, que é analisar o artigo 53 da Carta, aferindo, em especial, o nível de proteção conferido na União aos direitos fundamentais, e depois do breve excurso sobre aos trabalhos preparatórios, é tempo agora de enquadrar sistematicamente o artigo em apreço.

A norma do artigo 53 está inserida no Título VII, que acolhe as disposições gerais que regem a interpretação e a aplicação da Carta, denominadas pela doutrina como as cláusulas horizontais.

$\mathrm{O}$ artigo 51, epigrafado de âmbito de aplicação, determina, no n. ${ }^{\circ} 1$, que as disposições da Carta têm por destinatários as instituições, órgãos e organismos da União, na observância do princípio da subsidiariedade, bem como os Estados-Membros, apenas quando apliquem o direito da União. Assim sendo, devem respeitar os direitos, observar os princípios e promover a sua aplicação, de acordo com as respetivas competências e observando os limites das competências conferidas à União pelos Tratados.

O No 2, por sua vez, estabelece que a Carta não torna o âmbito de aplicação do direito da União extensivo a competências que não sejam as da União, não cria quaisquer novas atribuições ou competências para a União, nem modifica as atribuições e competências definidas pelos Tratados.

Ora, o artigo 51, reiterando o princípio da subsidiariedade, impõe a aplicação da Carta à União, tal como aos Estados-Membro, a estes apenas quando apliquem o direito da União. Esta referência ao direito da União, que podia suscitar algumas controvérsias, foi clarificada pelo TJ, que adotou uma interpretação alargada. As- 
sim, a expressão em apreço abrange não só a aplicação ou implementação de normas europeias, mas também a recusa de aplicação ou a derrogação dessas normas, com fundamento numa exceção prevista pelo direito da União. É, assim, patente a jurisprudência da vinculação ampla dos Estados-Membros ao direito da União.

Por sua vez, o artigo 52, referente ao âmbito e interpretação dos direitos e dos princípios, estabelece, no No 1 , que qualquer restrição ao exercício dos direitos e liberdades reconhecidos pela Carta deve ser prevista por lei e respeitar o conteúdo essencial desses direitos e liberdades. Na observância do princípio da proporcionalidade, essas restrições só podem ser introduzidas se forem necessárias e corresponderem efetivamente a objetivos de interesse geral reconhecidos pela União, ou à necessidade de proteção dos direitos e liberdades de terceiros. O No 2 dispõe, por seu turno, que os direitos reconhecidos pela Carta que se regem por disposiçôes constantes dos Tratados são exercidos de acordo com as condições e limites por eles definidos.

Ora, no que toca à matéria das restrições, a Carta consagrou o entendimento que já resultava da jurisprudência do TJ e que está consagrado na generalidade das constituições nacionais, sendo propugnado pelos tribunais constitucionais dos Estados-Membros.

Por outro lado, e nos termos do No 3 do mesmo artigo, na medida em que a Carta contenha direitos correspondentes aos direitos garantidos pela Convenção Europeia para a Proteção dos Direitos do Homem e das Liberdades Fundamentais, o sentido e o âmbito desses direitos são iguais aos conferidos por essa Convenção. Porém, esta disposição não obsta a que o direito da União confira uma proteção mais ampla.

Assim sendo, a norma em apreço, impondo a regra de paridade de âmbito e sentido entre a CEDH e a Carta, declara a CEDH como o standard mínimo de proteção. Por isso mesmo, é de extrema importância na leitura do artigo 53, analisado de seguida.

O No 4 do artigo 52 consagra outra regra importante. Vejamos. Na medida em que a Carta reconheça direitos fundamentais decorrentes das tradiçóes constitucionais comuns aos Estados-Membros, tais direitos devem ser interpretados de harmonia com essas tradições.

Na verdade, o referido No 4 impõe a adoção de um novo critério interpretativo, a saber, o critério da interpretação conforme às tradições constitucionais comuns dos Estados-Membros, nos casos em que os direitos fundamentais decorrem dessas tradições. Tutela-se, assim, o elevado nível de proteção reiterado pela União, tendo em conta, e salvaguardando, as particularidades dos Estados-Membros. 
O No 5 do artigo em apreço estabelece, por sua vez, que as disposições da Carta que contenham princípios podem ser aplicadas através de atos legislativos e executivos tomados pelas instituições, órgãos e organismos da União e por atos dos Estados-Membros quando estes apliquem o direito da Uniáo, no exercício das respetivas competências. Só serão invocadas perante o juiz tendo em vista a interpretação desses atos e a fiscalização da sua legalidade.

Nos termos do No 6, as legislaçôes e práticas nacionais devem ser plenamente tidas em conta tal como precisado na Carta, e, de acordo com o № 7, os órgãos jurisdicionais da União e dos Estados-Membros têm em devida conta as anotações destinadas a orientar a interpretação da Carta.

Acrescente-se, ainda, dado que é a última cláusula horizontal consagrada na Carta, que o artigo 54, epigrafado de proibição do abuso de direito, prescreve que nenhuma disposição da Carta deve ser interpretada no sentido de implicar qualquer direito de exercer atividades ou praticar atos que visem a destruição dos direitos ou liberdades por ela reconhecidos ou restriçôes desses direitos e liberdades maiores do que as previstas.

\subsection{Análise do artigo 53}

O artigo 53, epigrafado de nível de proteção, acolheu, depois de longas discussóes sobre a matéria, a sexta redação lavrada pelo Comité e aprovada pela Convenção.

Ora, de acordo com o artigo em apreço, nenhuma disposição da Carta deve ser interpretada no sentido de restringir ou lesar os direitos do Homem e as liberdades fundamentais reconhecidos, nos respetivos âmbitos de aplicação, pelo direito da União, o direito internacional e as Convenções internacionais em que são Partes a União ou todos os Estados-Membros, nomeadamente a Convenção Europeia para a Proteção dos Direitos do Homem e das Liberdades Fundamentais, bem como pelas Constituições dos Estados-Membros.

A doutrina que se debruça sobre o tema não é unânime. De facto, a norma em apreço tem sido interpretada de diferentes formas, o que nos permite elencar duas correntes de pensamento díspares.

Em traços largos, para alguns autores, o artigo 53 consagra o denominado princípio do nível mais elevado de proteção dos direitos fundamentais, entendido como um verdadeiro critério de resolução de conflitos. Para outros, refutando a tese de que se trata de uma cláusula de não retrocesso, a norma apenas reafirma o princípio do primado do direito da União Europeia. 
Com efeito, Leonard Besselink, Maria Luísa Duarte e Fausto Quadros, entre outros, entendem que o artigo 53 consagra o princípio do nível mais elevado de proteção em matéria de direitos fundamentais.

Para esta corrente de pensamento, este princípio consubstancia um novo critério a tomar em consideração nos casos de colisão de direitos. É, assim, uma verdadeira norma de resolução de conflitos que manda aplicar os preceitos mais protetores, devendo considerar-se como assegurando uma proteção mais elevada as disposições mais favoráveis ao indivíduo.

Esta cláusula de não retrocesso garante a tutela mais favorável dos direitos fundamentais, reconhecendo a importância do diálogo entre a União e os outros ordenamentos jurídicos.

Assim sendo, a Carta só será aplicada quando garantir uma maior proteção dos direitos fundamentais. No que toca especificamente às relaçóes com os ordenamentos jurídicos nacionais, a Carta só poderá prevalecer naqueles casos em que os direitos constitucionais nacionais, no âmbito de aplicação do direito europeu, são menos protetores. Por conseguinte, as constituições nacionais serão o parâmetro de validade dos atos jurídicos nas matérias de competência concorrente entre a União e os Estados-Membros, pelo que o TJ está obrigado a considerá-las na resolução dos processos que são interpostos.

Os autores que defendem a aplicação do princípio do nível mais elevado de proteção entendem, pois, que o princípio do primado do direito da União cede a favor da aplicação dos direitos de outros ordenamentos jurídicos, inclusivamente das ordens jurídico-constitucionais nacionais, sempre que estes se mostrem mais protetores do indivíduo.

Do lado oposto, encontramos autores como Ingolf Pernice, Jonas Liisberg, Erich Vranes e Joseph Weiler, que, reiterando o princípio do primado do direito da União, negam a existência e a consequente aplicabilidade do princípio do nível mais elevado de proteção.

Os pensadores mais radicais afirmam que a norma do artigo 53 é inútil, uma vez que, tendo em consideração os trabalhos preparatórios e o propósito inicial de reconhecer a CEDH como o standard mínimo, tal já se retira de outras disposiçóes, pelo que a norma não acrescenta nada de novo. De facto, o artigo 52 determina que a $\mathrm{CEDH}$ é o patamar abaixo do qual a proteção da Carta não pode descer. Por isso mesmo, alguns autores defendem a eliminação da norma contida no artigo 53 da Carta.

Com um entendimento mais moderado, outros autores alvitram que a Carta, enquanto catálogo de direitos, não visa resolver quaisquer conflitos de normas, não havendo fundamento para excecionar o princípio do primado do direito da 
União. Na verdade, o único parâmetro admissível para aferir a validade das normas europeias é formado pelos Tratados e, a partir da entrada em vigor do Tratado de Lisboa, que atribuiu força vinculativa à Carta, pela própria Carta dos Direitos Fundamentais da União Europeia.

A conformidade do direito da União com os princípios e direitos fundamentais avalia-se, pois, através da verificação do cumprimento dos pressupostos consagrados nas normas europeias, que se concretizam no respeito pela $\mathrm{CEDH}$ e no princípio da proporcionalidade, não cabendo a aplicação dos vários regimes nacionais nem das constituições dos Estados-Membros.

Note-se que a União, ao longo dos anos, têm construído uma identidade constitucional própria, pelo que os valores culturalmente associados a um determinado Estado não devem ser estendidos a outros sem mais nem, em última instância, à ordem supranacional que se traduz na União Europeia.

$\mathrm{Na}$ verdade, sustenta-se, os princípios do primado, da integridade, da aplicação uniforme, da unidade substantiva e da eficácia da ordem jurídica europeia conquistados ao longo dos anos não podem ser relegados para segundo plano, em favorecimento do princípio do nível mais elevado de proteção. Além de que, este princípio, ao favorecer, claramente, os indivíduos, levaria à máxima limitação possível dos poderes públicos, o que nem sempre se mostra positivo.

Para alguns apologistas desta corrente, a referência normativa aos respetivos âmbitos de aplicação permite afastar a interpretação segundo a qual os direitos fundamentais reconhecidos pelas constituiçôes nacionais poderiam ser considerados parâmetro de controlo de validade dos atos da União. Na realidade, os direitos reconhecidos a nível nacional só se tornam preponderantes quando estão em causa matérias da exclusiva competência dos Estados-Membros.

Para finalizar, saliente-se que alguns autores afirmam que a norma parte do pressuposto que a interpretação dos preceitos de direitos fundamentais é clara e inequívoca, podendo-se comparar facilmente os níveis de proteção. Porém, as normas são, na maioria dos casos, complexas, pelo que a tarefa de avaliar qual a norma que protege mais é de difícil execução, se não mesmo impossível.

\subsection{Análise do Acórdão Melloni}

O Acórdão Melloni, datado de 26 de fevereiro do corrente ano, foi proferido pelo TJ no âmbito do Processo C-399/11. O pedido de decisão prejudicial apresentado pelo Tribunal Constitucional Espanhol (TCE) deu entrada no TJ no dia 28 de julho de 2011, tendo sido apresentadas as conclusões do Advogado-Geral Yves Bot em 2 de outubro de 2012. 
O acórdão em apreço, cujo objeto se centra na interpretação e eventual invalidade do artigo $4^{\circ}$-A, No 1 , da Decisão-Quadro 2002/584/JAI, alterada pela Decisão-Quadro 2009/299/JAI, mostra-se especialmente importante na nossa análise, uma vez que se debruça sobre o artigo 53 da Carta.

No âmbito do reenvio prejudicial, o TCE formulou três questóes. Em primeiro lugar, perguntou se o artigo $4^{\circ} \mathrm{A}$, No 1, da DecisãoQuadro 2002/584/ JAI, na sua redação em vigor dada pela DecisãoQuadro 2009/299/JAI, deve ser interpretado no sentido de que impede as autoridades judiciais nacionais, nos casos indicados nessa mesma disposição, de sujeitar a execução de um mandado de detenção europeu à condição de a condenação em causa poder ser objeto de novo julgamento ou de recurso, a fim de garantir os direitos de defesa da pessoa sobre a qual recai o mandado.

Em caso de resposta afirmativa à primeira questão, perguntou-se, em segundo lugar, se o No 1 do artigo $4^{\circ}$ A da DecisãoQuadro 2002/584/JAI é compatível com as exigências que resultam do direito de ação efetiva e do direito a um processo equitativo, previstos no artigo $47 \mathrm{da}$ Carta, assim como dos direitos de defesa garantidos no artigo 48, No 2, do mesmo diploma.

Em terceiro lugar, e em caso de resposta afirmativa à segunda questão, questionou-se se o artigo 53 da Carta, interpretado de modo sistemático, em conjugação com os direitos reconhecidos nos artigos 47 e 48, permite que um EstadoMembro sujeite a entrega de uma pessoa que tenha sido condenada sem ter estado presente no julgamento à condição de essa condenação poder ser objeto de novo julgamento ou de recurso no Estado requerente, conferindo assim a esses direitos um nível de proteção mais elevado do que aquele que decorre do direito da União Europeia, a fim de evitar uma interpretação que limite ou lese um direito fundamental reconhecido pela constituição desse EstadoMembro.

Importa começar por analisar o quadro jurídico que delimita o caso em apreço.

$\mathrm{Na}$ Carta, são de destacar os artigos 47, que estabelece o direito a um julgamento equitativo, tal como os direitos a aconselhamento, defesa e representação em juízo, e 48, que consagra os direitos de defesa do arguido.

Destaquem-se, ainda, os artigos 52 e 53 . O primeiro determina que o sentido e o âmbito dos direitos consagrados na Carta que correspondem aos direitos garantidos na $\mathrm{CEDH}$ são iguais aos conferidos por essa mesma Convenção. No entanto, tal não obsta a que o direito da União confira uma proteção mais ampla.

Por seu turno, o artigo 53 proíbe interpretaçôes que restrinjam ou lesem os direitos fundamentais reconhecidos, nos respetivos âmbitos de aplicação, pelo direito da União, o direito internacional e as Convenções internacionais, bem como pelas Constituições dos Estados-Membros. 
Relativamente ao direito derivado aplicável no caso concreto, recorde-se que a Decisão-Quadro 2002/584/JAI do Conselho, de 13 de junho de 2002, relativa ao mandado de detenção europeu e aos processos de entrega entre os EstadosMembros, na sua versão originária, consagrava, no artigo $5^{\circ}$, a possibilidade de sujeitar a execução do mandado, emitido na sequência de uma decisão proferida na ausência do arguido, ao fornecimento de garantias suficientes de que seria admissível um recurso ou um novo julgamento e de que o julgamento seria feito na presença do arguido.

Esta Decisão-Quadro foi, no entanto, alterada pela Decisão-Quadro 2009/299/ JAI do Conselho, de 26 de fevereiro de 2009, que visou reforçar os direitos processuais das pessoas, facilitar a cooperação judiciária em matéria penal e promover a aplicação do princípio do reconhecimento mútuo no que se refere às decisões proferidas na ausência do arguido.

Nos considerandos desta Decisão-Quadro de 2009 referia-se, pertinentemente, que o direito do arguido a estar presente no julgamento, incluído no direito a um processo equitativo consagrado na $\mathrm{CEDH}$ tal como interpretada pelo TEDH, não é um direito absoluto, pelo que pode ser renunciado por livre vontade do arguido, expressa ou implicitamente, desde que o faça de forma inequívoca.

Além disso, sublinhou-se a grande diversidade de decisões, prejudiciais para a cooperação judiciária, e que a definição das garantias suficientes exigidas estava na discricionariedade dos Estados-Membros, o que despoletou a necessidade de prever, de forma clara, motivos comuns para o não reconhecimento das decisões proferidas na sequência de um julgamento em que o arguido não tenha estado presente.

Nos considerandos presumia-se, desde logo, que, se a pessoa, tendo tido conhecimento do julgamento previsto, tiver sido representada no julgamento por um defensor ao qual conferiu mandato para o efeito, assegurando uma assistência jurídica prática e efetiva, optou deliberadamente por ser representada por um defensor, em vez de estar presente no julgamento.

Ora, a Decisão-Quadro 2009/299, que suprimiu o artigo $5^{\circ}$ previsto na redação originária da Decisão-Quadro 2002/584, introduziu o artigo $4^{\circ}$-A, que se refere precisamente às decisóes proferidas na sequência de um julgamento em que o interessado não compareceu pessoalmente.

O referido artigo $4^{\circ}$-A acolhe casos facultativos de não execução do mandado de detenção europeu. Nos termos do No 1 , o facto de o interessado não ter estado presente no julgamento que conduziu à condenação é um motivo facultativo de não execução do mandado de detenção europeu emitido para efeitos de execução de uma pena ou de uma medida de segurança privativas de liberdade. Esta faculdade prevê, contudo, quatro exceções que privam a autoridade judiciária da 
possibilidade de recusar a execução do mandado de detenção europeu em causa, que se opõem a que a autoridade judiciária de execução subordine a entrega de uma pessoa condenada sem ter estado presente no julgamento à possibilidade de uma revisão do julgamento, na presença da pessoa.

Feito este breve excurso sobre o quadro jurídico, e entrando no processo principal, lembre-se que o que estava em causa era a execução de um mandado de detenção europeu emitido pelas autoridades italianas para execução da condenação a uma pena de prisão aplicada em julgamento sem a presença do arguido.

Com efeito, e sintetizando a matéria de facto, em 1993, o Tribunale di Ferrara de Itália emitiu dois mandados de detenção contra o Senhor Melloni, uma vez que este iria ser julgado e considerou-se importante o arguido estar presente no seu julgamento. Em 1996, a Audiencia Nacional de Espanha, estando o arguido neste país, declarou que se justificava efetivamente a extradição de Melloni para Itália, para aí ser julgado pelos factos constantes dos mandados. No entanto, foi concedida liberdade mediante caução e Melloni fugiu, não chegando a ser entregue às autoridades italianas.

Passado um ano, o Tribunale di Ferrara, declarando que Melloni não tinha comparecido no julgamento, ordenou que as notificações passassem a ser feitas aos advogados da sua confiança e por ele designados. Em 2000, esse mesmo tribunal, depois de o julgamento ter decorrido na ausência do arguido, proferiu acórdão condenando Melloni, frise-se, sem ter estado presente no julgamento, à pena de dez anos de prisão como autor do crime de falência fraudulenta. Esta mesma decisão foi confirmada em 2003 pela Corte d'appello di Bologna.

Em 2004, os advogados que patrocinaram Melloni interpuseram um recurso na Corte Suprema di Cassazione, cujo provimento foi posteriormente negado. Nessa mesma altura, a Corte d'appello di Bologna emitiu mandado de detenção para execução da pena proferida pelo Tribunale di Ferrara.

Volvidos 4 anos, Melloni foi, então, detido pela polícia espanhola e o mandado de detenção, emitido em 2004, remetido à Audiencia Nacional.

Melloni opôs-se à sua entrega às autoridades italianas, tendo fundamentado a sua oposição em duas ordens de argumentos.

Por um lado, afirmou que, na fase de recurso, tinha designado outro advogado, revogando, assim, o mandato dos dois advogados que anteriormente o tinham representado, aos quais, apesar disso, continuaram a ser dirigidas as notificações.

Por outro lado, alegou que a lei processual italiana não previa a possibilidade de se interpor recurso das condenaçôes proferidas na ausência do arguido no julgamento e que a execução do mandado de detenção europeu deveria estar 
subordinada à condição de a República Italiana garantir a possibilidade de ser interposto recurso do acórdão que o condenou.

Apesar destes argumentos expendidos por Melloni, a Audiencia Nacional decidiu, efetivamente, entregar Melloni às autoridades italianas, considerando que não tinha sido provado que os advogados por ele designados tivessem deixado de o representar a partir de 2001 e que os direitos de defesa tinham sido respeitados, uma vez que Melloni, enquanto arguido, teve conhecimento do processo que ia ser instaurado, não compareceu voluntariamente no julgamento e designou dois advogados para o representar e defender, os quais, nessa qualidade, intervieram em primeira, segunda e terceira instâncias, esgotando assim as vias de recurso.

Melloni, descontente, interpôs recurso de amparo no TCE, alegando, em síntese, que foi violado o conteúdo essencial do direito a um processo equitativo e o princípio da dignidade humana, uma vez que foi postergada a condição de a entrega da pessoa condenada estar subordinada à possibilidade de recurso, com vista à salvaguarda dos direitos de defesa. O TCE, admitindo o recurso de amparo apresentado, suspendeu, na sua sequência, a execução do despacho de entrega.

Aqui chegados, mostra-se pertinente focar alguns dos aspetos essenciais da jurisprudência do TCE nesta matéria, para uma melhor compreensão do caso em apreço.

Ora, o TCE tem entendido que constitui uma violação do direito a um processo equitativo, lesando o seu conteúdo essencial de tal modo que afeta a dignidade humana, a decisão dos órgãos jurisdicionais espanhóis de permitirem a extradição para Estados que, em caso de crime muito grave, validam as condenaçôes proferidas na ausência do arguido, sem subordinarem a entrega da pessoa condenada à condição de ela poder impugnar essas condenações e salvaguardar, assim, os seus direitos de defesa.

Esta corrente jurisprudencial foi aplicada no quadro do procedimento de entrega instituído pela DecisãoQuadro 2002/584, dado que o artigo $5^{\circ}$, $\mathrm{N}^{\circ} 1$, previa a possibilidade de a execução de um mandado de detenção europeu emitido para cumprimento de uma condenação proferida na ausência do arguido no julgamento estar, ao abrigo do direito do EstadoMembro de execução, subordinada, designadamente, à condição de a autoridade judicial de emissão dar garantias consideradas suficientes para assegurar à pessoa sobre a qual recai o mandado de detenção a possibilidade de pedir um novo julgamento que salvaguarde os direitos de defesa no EstadoMembro emissor e de ser julgada presencialmente.

Note-se que na vigência deste artigo $5^{\circ}$, No 1 , o TCE julgou procedente um recurso de amparo no qual estava em causa um despacho que ordenou a entrega 
de uma pessoa à Roménia, em execução de um mandado de detenção europeu, para cumprimento de uma pena de quatro anos de prisão proferida na ausência do arguido no julgamento, por, precisamente, não se ter indicado a exigência de a condenação em questão poder ser revista. Nesse caso concreto, o referido acórdão do TCE rejeitou a argumentação da Audiencia Nacional, segundo a qual a condenação não foi verdadeiramente proferida na ausência do arguido, uma vez que o recorrente mandatou um advogado que compareceu em juízo como seu defensor particular.

O TCE, confrontado com o caso Melloni, adianta que a grande dificuldade reside no facto de a DecisãoQuadro 2009/299 ter suprimido o artigo 5º, No 1, da DecisãoQuadro 2002/584 e inserido um novo artigo $4^{\circ} \mathrm{A}$. Ora, o referido artigo $4^{\circ} \mathrm{A}$ impede que se recuse a execução do mandado de detenção europeu emitido para efeitos de cumprimento de uma pena ou medida de segurança privativas de liberdade no caso de a pessoa não ter estado presente no julgamento que conduziu à decisão, quando esta, tendo conhecimento do julgamento previsto, conferiu mandato a um defensor designado por si ou pelo Estado para a sua defesa em tribunal e foi efetivamente representada por esse defensor no julgamento.

Ora, no litígio que originou a fiscalização de constitucionalidade em apreço, segundo refere o órgão jurisdicional de reenvio, provou-se que Melloni mandatou dois advogados da sua confiança, aos quais o Tribunale di Ferrara notificou a realização futura do julgamento, pelo que ele tinha conhecimento do mesmo. Provou-se, igualmente, que Melloni foi efetivamente defendido por esses dois advogados no julgamento em primeira instância e nos posteriores recursos de segunda e terceira instâncias.

Vista a matéria de facto, adentremos, pois, na apreciação do TJ. Numa palavra, há que apurar se a DecisãoQuadro 2002/584 se opõe a que os órgãos jurisdicionais espanhóis subordinem a entrega de Melloni à possibilidade de a condenação em questão ser revista.

Tendo em conta o objeto deste trabalho, mostra-se particularmente pertinente analisar a terceira questão. Importa, porém, sublinhar que, no que concerne à primeira questão, o TJ pronunciou-se no sentido de que o artigo $4^{\circ} \mathrm{A}, \mathrm{N}^{\circ} 1$, da DecisãoQuadro 2002/584 deve ser interpretado no sentido de que se opõe a que a autoridade judiciária de execução, nos casos indicados nessa disposição, subordine a execução de um mandado de detenção europeu emitido para fins da execução de uma pena à condição de a condenação proferida na ausência do arguido no julgamento poder ser revista no EstadoMembro de emissão (ponto 46).

Relativamente à segunda questão, o TJ decidiu que o artigo $4^{\circ} \mathrm{A}, \mathrm{N}^{\circ} 1$, da DecisãoQuadro 2002/584 é compatível com as exigências que decorrem dos artigos 47 e 48, No 2, da Carta (ponto 54). 
Com a terceira questão, o órgão jurisdicional de reenvio pergunta, em substância, se o artigo 53 da Carta deve ser interpretado no sentido de que permite ao EstadoMembro de execução subordinar a entrega de uma pessoa condenada sem ter estado presente no julgamento à condição de a condenação poder ser revista no EstadoMembro de emissão, a fim de evitar uma violação do direito a um processo equitativo e dos direitos de defesa garantidos pela sua Constituição (ponto 55).

Quanto a esta questão, o TJ começa por notar que o TCE preconiza, à partida, a interpretação segundo a qual o artigo 53 da Carta autoriza, em geral, um EstadoMembro a aplicar o padrão de proteção dos direitos fundamentais garantido pela sua Constituição, quando este é mais elevado do que o que decorre da Carta, e a opôlo, se for caso disso, à aplicação de disposiçóes do direito da União. Esta interpretação permite, em especial, a um EstadoMembro subordinar a execução de um mandado de detenção europeu emitido tendo em vista executar uma decisão proferida na ausência do arguido no julgamento a condiçóes que tenham por objeto evitar uma interpretação que limite os direitos fundamentais reconhecidos pela sua Constituição ou que os viole, ainda que a aplicação de tais condiçõos não seja autorizada pelo artigo $4^{\circ} \mathrm{A}$, No 1 , da DecisãoQuadro 2002/584 (ponto 56).

Ora, o TJ é perentório: tal interpretação do artigo 53 da Carta não pode proceder (ponto 57).

Afastando, assim, o princípio do nível mais elevado de proteção, o TJ prossegue a sua argumentação afirmando que essa interpretação do artigo 53 da Carta viola o princípio do primado do direito da União, na medida em que permite a um EstadoMembro obstar à aplicação de atos do direito da União plenamente conformes à Carta, se não respeitarem os direitos fundamentais garantidos pela Constituição desse Estado (ponto 58).

Na verdade, é jurisprudência assente que, por força do princípio do primado do direito da União, que é uma característica essencial da ordem jurídica da União, a invocação, por um EstadoMembro, de disposições de direito nacional, ainda que de natureza constitucional, não pode afetar o efeito do direito da União no território deste Estado (ponto 59).

Não obstante, o TJ sublinha que o artigo 53 da Carta confirma que, quando um ato do direito da União exige medidas nacionais de execução, as autoridades e os órgãos jurisdicionais nacionais podem aplicar os padrões nacionais de proteção dos direitos fundamentais, desde que essa aplicação não comprometa o nível de proteção previsto pela Carta, conforme interpretada pelo TJ, nem o primado, a unidade e a efetividade do direito da União (ponto 60).

No caso concreto, no entanto, como já ficou exposto, o artigo 4o A, No 1 , da DecisãoQuadro 2002/584 não concede aos EstadosMembros a faculdade de 
recusar a execução de um mandado de detenção europeu, quando o interessado for abrangido por um dos quatro casos previstos nessa disposição (ponto 61).

O TJ recorda, além disso, que a adoção da DecisãoQuadro 2009/299, que inseriu a referida disposição na DecisãoQuadro 2002/584, visa remediar as dificuldades do reconhecimento mútuo das decisões proferidas na ausência da pessoa em causa do seu julgamento, que resultam da existência, nos EstadosMembros, de diferenças na proteção dos direitos fundamentais. Para esse efeito, a decisãoquadro procede a uma harmonização das condições de execução de um mandado de detenção europeu em caso de condenação na ausência do arguido, que reflete o consenso a que chegaram todos os EstadosMembros a respeito do alcance que importa dar, nos termos do direito da União, aos direitos processuais de que beneficiam as pessoas condenadas sem estarem presentes no julgamento, contra as quais é emitido um mandado de detenção europeu (ponto 62).

Por isso mesmo, permitir a um EstadoMembro invocar o artigo 53 da Carta para subordinar a entrega de uma pessoa condenada sem ter estado presente no julgamento à condição, não prevista pela DecisãoQuadro 2009/299, de a condenação poder ser revista no EstadoMembro de emissão, a fim de evitar que seja violado o direito a um processo equitativo e os direitos de defesa garantidos pela Constituição do EstadoMembro de execução, levaria, ao pôr em causa a uniformidade do padrão de proteção dos direitos fundamentais definidos por esta decisãoquadro, a violar os princípios da confiança e do reconhecimento mútuo que esta pretende reforçar e, assim, a comprometer a eficácia da referida decisãoquadro (ponto 63).

Respondendo, então, à terceira questão o TJ afirma que o artigo 53 da Carta deve ser interpretado no sentido de que não permite a um EstadoMembro subordinar a entrega de uma pessoa condenada sem ter estado presente no julgamento à condição de a condenação poder ser revista no EstadoMembro de emissão, a fim de evitar uma violação do direito a um processo equitativo e dos direitos de defesa garantidos pela sua Constituição (ponto 64).

\subsection{Apreciação crítica}

O TUE, ao atribuir a força jurídica dos Tratados à Carta, fundamentalizou formal e materialmente este catálogo de direitos, cuja aprovação remonta ao ano de 2000.

Se, por um lado, é indiscutível que a atribuição de força jurídica vinculativa à Carta consubstancia um passo decisivo e de capital importância para a União, por outro, favorece de forma substancial os conflitos constitucionais. 
Ora, a eventual colisão entre as normas constitucionais dos Estados-Membros e as da própria União encontrará resolução no artigo 53 da Carta, que tem sido interpretado de forma divergente pela doutrina.

Alguns pensadores defendem que o referido artigo 53 consagra o princípio do nível mais elevado de proteção. Para esta corrente, no caso de conflito entre normas constitucionais nacionais e europeias, deverá prevalecer a norma que confere ao indivíduo o nível de proteção mais elevado. Este princípio jurídico será, assim, de aplicar em caso de conflito entre normas comunitárias e normas nacionais de direitos fundamentais, simultaneamente mobilizáveis no mesmo caso.

Por outro lado, encontramos autores que afirmam que este artigo nada acrescenta ao regime europeu de tutela dos direitos fundamentais, sob pena de uma insuportável contradição ao princípio do primado do direito europeu.

O TJ, criado em 1952, foi o primeiro a afirmar o princípio do primado do direito da União, que tem reiterado ao longo de mais de 60 anos de jurisprudência. Atualmente, mais do que uma tradição jurisprudencial sedimentada, o princípio do primado do direito da União sobre os direitos dos Estados-Membros é uma concretização do valor do Estado de Direito consagrado no artigo $2^{\circ}$ do TUE, que espelha o aprofundamento do constitucionalismo europeu. Recorde-se que o Tratado de Lisboa optou por não inscrever formalmente o princípio do primado no articulado dos tratados, ao contrário do projeto de Tratado Constitucional, o que não obsta, todavia, a que este princípio seja reconhecido como estruturante da União Europeia.

O primado do direito da União sobre as normas dos Estados-Membros, incluindo as constitucionais, é indispensável para garantir a aplicação uniforme e efetiva daquele direito. Na senda de Freitas do Amaral e Nuno Piçarra, "o direito da UE prima sobre o direito nacional não por lhe ser superior, mas porque é materialmente competente para regular o caso concreto"6.

Preocupado em fazer do princípio do primado um instrumento de garantia da unidade substantiva do direito comunitário no conjunto formado pelos ordenamentos jurídicos nacionais, o TJ não encarou, num primeiro momento, a possibilidade da existência de eventuais limites àquele princípio, conferindo-lhe um valor absoluto. No entanto, cedo se verificaram incompatibilidades entre as normas de direito comunitário e as normas constitucionais nacionais, sobretudo no que toca aos direitos fundamentais, cujo respeito consubstancia um princípio geral do direito e um limite intrínseco ao princípio do primado. Por isso mesmo, o

6 Diogo Amaral e Nuno Piçarra, 2009, p. 17. 
que legitima, em última análise, o primado do direito da União é a sua compatibilidade com os princípios fundamentais, em especial com os direitos fundamentais.

O princípio do primado do direito da União, estabelecido, assim, pelo TJ, em estreita articulação com os tribunais nacionais, impõe, pois, a "garantia da efectiva sujeição das normas da União destinadas a prevalecer nas ordens jurídicas dos Estados-Membros a parâmetros de validade essencialmente coincidentes com os que integram o "núcleo duro" das constituições nacionais, a começar pelos direitos fundamentais"7.

No acórdão Melloni, que se pronuncia sobre o conteúdo do artigo 53 da Carta, o Tribunal decidiu aplicar o direito adequado ao caso concreto, independentemente de oferecer o nível de proteção mais elevado. O TJ sublinhou que crucial era o respeito pelo princípio da proporcionalidade, que se traduzisse na aplicação do direito ajustado ao caso concreto, isto é, que conferisse a proteção adequada.

Importa notar, aliás, que o próprio TCE não se pronunciou no sentido de que a legislação espanhola era mais protetora para o indivíduo neste caso em particular. Por isso mesmo, anda mal o TJ quando concorda com o condenado Melloni, asseverando que a legislação espanhola conferia uma proteção mais elevada. $\mathrm{Na}$ realidade, a legislação espanhola não confere nem pode conferir uma proteção mais elevada, sob pena de uma inaceitável impunidade no caso concreto.

Efetivamente, de forma infeliz, o TJ parece admitir que, no caso em apreço, havia uma violação dos direitos de defesa do arguido ao não estar presente em julgamento, quando, na verdade, não havia nem podia haver, induzindo, assim, em erro. Parece, pois, que o TJ não se demarcou da corrente que defende que o julgamento realizado na ausência do arguido não respeita os seus direitos de defesa.

Ora, deixemos cair, pois, dois pressupostos que têm sido afirmados falsamente.

O primeiro pressuposto falso é que o julgamento realizado na ausência do arguido é sempre violador dos seus direitos de defesa. De facto, o julgamento na ausência pode, em certos casos, respeitar os direitos de defesa do arguido, como é o caso do julgamento Melloni, no qual o arguido foi efetivamente defendido pelos advogados que contratou.

O segundo pressuposto falso diz respeito à legislação espanhola, vista como mais protetora. Ora, tal não é verdade. Vejamos. Se a legislação espanhola protegesse efetivamente mais o arguido, isso, na prática, traduzia-se na impunidade do mesmo. Por isso mesmo, a recusa da execução do mandado de detenção só é aceitável mediante a prova de que houve uma violação dos direitos de defesa,

7 Amaral e Piçarra, 2009, p. 13. 
violação essa que não se consumou no caso Melloni, uma vez que o arguido foi efetivamente representado e defendido pelos advogados que mandatou.

Certo é que o TJ não põe de lado a possibilidade de existirem normas nacionais mais protetoras dos direitos fundamentais dos indivíduos. E fá-lo de forma inteligente, não retirando efeito útil ao artigo 53 da Carta. No entanto, reitera, como sempre fez, o princípio do primado do direito da União Europeia, afastando, neste caso concreto, a aplicação do princípio do nível de proteção mais elevado.

O princípio do primado do direito da União, tal como os princípios da unidade e da efetividade, foram, assim, renovados pelo Tribunal, que os caracterizou como princípios topoi, verdadeiros limites ao âmbito de aplicação do artigo 53 da Carta.

O nível de proteção a aplicar em cada caso concreto deve ser o adequado, independentemente de, nos Estados-Membros, o direito em apreço ser protegido de forma mais intensa. A proteção adequada de um direito fundamental no âmbito dos objetivos da União obsta, assim, à aplicação do nível de proteção mais elevado do mesmo direito a nível nacional. No entanto, sublinhe-se, nada impede que, num determinado caso, a proteção adequada seja precisamente o nível de proteção mais elevado.

Assim, no Acórdão Melloni, o princípio do nível de proteção mais elevado foi afastado. No entanto, como foi referido, poderá ser aplicado noutros casos. Ora, esta jurisprudência é um passo no sentido de se assegurar a preferência, em casos de aplicação concorrente, pelas normas que impliquem uma garantia mais intensa daqueles mesmos direitos, sejam elas de origem nacional ou comunitária.

$\mathrm{O}$ artigo $53 \mathrm{da}$ Carta é, pois, um princípio interpretativo, que tem como destinatário primeiro o TJ. A interpretação adotada pelo TJ no caso Melloni permite a subsistência e a coexistência de diversas formas de tutela, conferindo uma proteção plural e multinível aos direitos fundamentais. Ao adotar-se o nível de proteção ajustado ao caso está, pois, a conferir-se um elevado nível de proteção.

Frise-se, para concluir, que a primazia da Carta só se aplicará no contexto das matérias comunitárias, afastando-se nas áreas de atuação das autoridades estaduais que estejam sujeitas exclusivamente ao direito nacional, onde as Leis Fundamentais desempenham o papel principal.

\section{REFERÊNCIAS}

Amaral, Diogo Freitas do; Piçarra, Nuno, "O Tratado de Lisboa e o princípio do primado do direito da União Europeia: uma "evolução na continuidade"”, in Revista de Direito Público, No 1, janeiro/junho de 2009, pp. 9-56. 
Uniāo Europeia, Carta dos Direitos Fundamentais da Uniāo Europeia, Jornal Oficial da Uniāo Europeia, C 326/391, 26.10.2012.

Maduro, Miguel Poiares, "O superavit democrático europeu”, in Análise Social, Vol. XXXVI (158-159), 2001, pp. 119-152.

PiçARra, Nuno (Coord.), A Uniāo Europeia segundo o Tratado de Lisboa Aspectos Centrais, Coimbra, Almedina, 2011.

Acórdãos do Tribunal de Justiça consultados (Disponiveis em: <http:/leur-lex.europa.eul JURISIndex.do?ihmlang=pt>; Acesso entre 7 de Janeiro e 30 de Agosto de 2013):

Acórdão de 5 de fevereiro de 1963, no Processo 26-62

Acórdão de 15 de julho de 1964, no Processo 6-64

Acórdão de 12 de novembro de 1969, no Processo 29-69

Acórdão de 17 de dezembro de 1970, no Processo 11-70

Acórdão de 14 de maio de 1974, no Processo 4-73

Acórdão de 28 de outubro de 1975, no Processo 36-75

Acórdão de 9 de março de 1978, no Processo 106/77

Acórdão de 13 de dezembro de 1979, no Processo 44/79

Acórdão de 29 de outubro de 1980, no Processo 138/79

Acórdão de 18 de maio de 1982, no Processo 155/79

Acórdão de 11 de julho de 1985, nos Processos Apensos 60 e 61

Acórdão de 13 de julho de 1989, no Processo 5/88

Acórdão de 18 de junho de 1991, no Processo C-260/89

Acórdão de 4 de outubro de 1991, no Processo C-159/90

Acórdão de 25 de junho de 1997, no Processo C-368/95

Acórdão de 11 de janeiro de 2000, no Processo C-285/98

Acórdão de 5 de outubro de 2000, no Processo C-376/98

Acórdão de 12 de junho de 2003, no Processo C-112/00

Acórdão de 14 de outubro de 2004, no Processo C-36/02

Acórdão de 12 de dezembro de 2006, no Processo C-380/03

Acórdão de 3 de maio de 2007, no Processo C-303/05

Acórdão de 11 de dezembro de 2007, no Processo C-438/05

Acórdão de 18 de dezembro de 2007, no Processo C-341/05

Acórdão de 8 de março de 2011, no Processo C-34/09

Acórdão de 26 de fevereiro de 2013, no Processo C-399/11 